\title{
Risk Factors for Atherosclerosis in Students of a Private University in São Paulo - Brazil
}

\author{
Lísia Marcílio Rabelo, Roberto Márcio Viana, Maria Arlete Schimith, Rose Vega Patin, Mara Andréa Valverde, \\ Regina Célia Denadai, Ana Paula Cleary, Sandra Lemes, Caio Auriemo, Mauro Fisberg, \\ Tania Leme da Rocha Martinez
}

\author{
São Paulo, SP - Brazil
}

\begin{abstract}
Objective - To characterize the risk profile for atherosclerosis (AS) in adolescents and young adults of a private university in São Paulo.
\end{abstract}

Methods - Clinical, nutritional, and laboratory parameters were evaluated in 209 students of both genders aged 17 to 25 years. In addition to determination of the lipid profile, the association of its abnormal values with other risk factors for AS was also investigated.

Results - Increased levels of total cholesterol, LDL-C and triglycerides (TG) were observed in $9.1 \%, 7.6 \%$ and $16.3 \%$ of the students, respectively, and decreased levels of $H D L-C$ in $8.6 \%$ of them. Prevalence of the remaining risk factors analyzed was elevated: sedentary life style (78.9\%); high intake of total fat (77.5\%); high cholesterol intake (35.9\%); smoking, hypertension (15.8\%) and obesity (7.2\%). There was an association between elevated LDL-C and TG levels and sedentary life style and body mass index.

Conclusion - The high prevalence of risk factors for $A S$ in young individuals draws attention to the need for adopting preventive plans.

Key words: atherosclerosis, risk factors, adolescents, young adults
Centro de Estudos e Pesquisas em Saúde e Nutrição da Universidade São Marcos and Universidade Federal de São Paulo/Escola Paulista de Medicina - São Paulo Mailing address: Lísia Marcílio Rabelo - Av. Euclides da Cunha, 475/1301 40150-120 - Salvador, BA - Brazil
Atherosclerosis, a chronic disease of multifactorial etiology ${ }^{1}$, is one of the major causes of morbidity and mortality in the adult population, including Brazil ${ }^{2,3}$.

Traditionally, atherosclerosis (AS) is considered a typical disease of middle age. Coronary heart disease (CHD), its most frequent and lethal form, reaches a significant index of incidence from 45 years onwards in men and 55 years onwards in women. However, the atherosclerotic process starts several decades before its clinical manifestations (myocardial infarction, cerebral stroke, peripheral vascular disease) arise ${ }^{4}$, as data obtained from autopsy studies indicate ${ }^{5-7}$

Generally, there is a long asymptomatic period preceding the clinical manifestations of atherosclerosis ${ }^{8}$. The rate of progression of the atherosclerotic process is variable, depending on the number and prevalence of risk factors (RF) identified ${ }^{4}$. Most risk factors begin or are acquired in childhood $^{9}$, and tend to persist over time ${ }^{10}$.

Due to the increasing and high cost of the treatment of this disease, investments in preventive measures have become a priority ${ }^{4}$. Understanding of the magnitude of multiple RFs for AS and identifying them in the different age ranges are essential for devising effective prevention plans. Preventive measures should fit with the reality of the local environment, so that they can be implemented effectively. In addition, developing a plan that is appropriate for the local reality where it is going to be implemented is fundamental.

Considering the low number of national epidemiological studies of the risk factors for atherosclerosis in Brazil, our objective was to describe the frequency of some RFs for AS in adolescents and young adults in São Paulo, taking gender into consideration. We also aimed to identify the RFs associated with total cholesterol (TC), and elevated LDL-cholesterol and triglyceride (TG) levels, and with low HDL-cholesterol levels.

\section{Methods}

During the $1^{\text {st }}$ semester of 1997 , we evaluated 209 
freshmen of both genders, ranging in age from 17 to 25 years, attending a private university in São Paulo. The evaluation process consisted of three steps (clinical, nutritional and laboratory parameters) and the participation was voluntary. During the clinical evaluation, the freshmen answered a standardized questionnaire aiming to investigate the presence of RFs for AS and they underwent a physical examination. Anthropometric (weight and height) and nutritional (food record of $24 \mathrm{~h}$ ) data were obtained during the nutritional evaluation. The choice of the $24 \mathrm{~h}$ food record as an instrument to evaluate total fat and cholesterol intake was based on the need for a qualitative rather than quantitative analysis. Through biochemical analysis, the values of TC and its fractions, TG and glycemia were obtained. Association of alterations in the lipid profile with other RFs, such as positive history for AS, hypertension, diabetes mellitus, obesity, smoking, diet, and sedentary life style was also investigated.

Lipid profile values were analyzed according to the II Consenso Brasileiro sobre Dislipidemia (Brazilian Consensus on Dyslipidemia) ${ }^{11}$. This recomendation establishes distinct reference values for age groups from 2 to 19 years and $\geq 20$ years. Therefore, the students in our study were divided into two groups according to age: subjects aged 17 to 19 years and subjects aged 20 to 25 years.

The presence of $1^{\text {st }}$ degree relatives with manifest AS (CHD and/or cerebrovascular disease and/or peripheral vascular disease) under the age of 55 years for males and 65 years for females was considered as a positive family history ${ }^{11}$.

Regarding blood pressure, the reference values adopted adhered to the recommendations of the V Joint National Committee ${ }^{12}$, defining hypertension as diastolic pressure $\geq 90 \mathrm{mmHg}$ and systolic pressure $\geq 140 \mathrm{mmHg}$.

The diagnosis of diabetes mellitus (fasting glycemia $\geq 126 \mathrm{mg} / \mathrm{dL}$ ) adhered to the standards of the Expert Committee on the Diagnosis and Classification of Diabetes Mellitus ${ }^{13}$.

According to body mass index (BMI), individuals were classified as follows: undernourished (BMI $<18.5 \mathrm{~kg}$ / $\mathrm{m}^{2}$ ); eutrophic $\left(\mathrm{BMI} \geq 18.5\right.$ and $\left.\leq 24.99 \mathrm{~kg} / \mathrm{m}^{2}\right)$; degree I of overweight (BMI $\geq 25$ and $\left.\leq 29.99 \mathrm{~kg} / \mathrm{m}^{2}\right)$; degree II of overweight (BMI $\geq 30$ and $\left.\leq 39.99 \mathrm{~kg} / \mathrm{m}^{2}\right)$; degree III of overweight $\left(\mathrm{BMI} \geq 40 \mathrm{~kg} / \mathrm{m}^{2}\right)^{14}$. Those with $\mathrm{BMI} \geq 30 \mathrm{~kg} / \mathrm{m}^{2}$ were considered obese ${ }^{11}$.

Individuals who smoked regularly, inhaling the smoke, an average of three or more cigarettes per day, for a period $\geq 1$ year, were considered smokers ${ }^{15}$.

Total fat intake $>30 \mathrm{~g}$ and cholesterol intake $>300 \mathrm{mg} /$ day was classified as excessive ${ }^{11}$.

Students denying a regular practice of physical activity with a frequency $\geq$ twice a week and minimal duration of 30 min were considered sedentary.

In the statistical analysis, to characterize the lipid profile regarding gender, the mean values were compared using the Student's $t$ test, when the variables were homogeneous. When the variables were heterogeneous, the means were compared using Kruskal-Wallis' test. Com- parison of the variances was made by using the Bartlett's test. The possible association of RFs for AS with the values of lipid profile was evaluated by means of the chisquare test using Yates' correction. In all analyses, the significance level used was $5 \%$.

\section{Results}

Of the 209 students evaluated, $72.2 \%$ were women and $52.6 \%$ were in the age range of 17 to 19 years.

Data regarding the values of the lipid profile (mean, minimum and maximum) according to gender are shown in table I. Women had a mean HDL-C level higher than men did, with no statistically significant differences when compared with other mean values.

Dyslipidemias, characterized by increased levels of TC and LDL-C, occurred in $9.1 \%$ and $7.6 \%$ of the sample, respectively. However, TC levels above that which is considered desirable (borderline and high) were observed in $39.7 \%$ of the women and $29.3 \%$ of the men ( $p=0.215)$. Elevated levels of LDL-C were also higher in women (19.9\%) when compared with those found in men $(15.5 \%)(\mathrm{p}=0.536)$.

Reduced levels of HDL-C were observed in $8.6 \%$ of the students, and this percentage was higher in men $(17.2 \%)$ than in women $(5.3 \%)(\mathrm{p}=0.013)$.

Hypertriglyceridemia was found in $16.3 \%$ of the sample. Increased levels of TG were higher in men $(24.1 \%)$ than in women $(13.2 \%)(\mathrm{p}=0.088)$.

Regarding the other RFs analyzed, sedentary life style, which occurred in $78.9 \%$ of the sample, was the most prevalent RF followed by high total fat intake (77.5\%). Smoking and hypertension had the same prevalence $(15.8 \%)$. From the 33 hypertensive individuals, $60.6 \%$ were male. Obesity was observed in $7.2 \%$ of the sample, and its frequency was greater in women (tab. II).

Statistically significant associations of sedentary life style with LDL-C $(\mathrm{p}=0.050)$ and $\mathrm{TG}(\mathrm{p}=0.032)$ levels above the desired values were observed, as well as an association of BMI with TC ( $\mathrm{p}=0.011), \mathrm{LDL}-\mathrm{C}(\mathrm{p}=0.030)$ and TG $(\mathrm{p}=0.007)$ levels. BMI showed a directly proportional relation to $\mathrm{TC}$ and LDL-C levels, and the greatest percentage of increased serum TG levels was observed in obese students $\left(\mathrm{BMI} \geq 30 \mathrm{~kg} / \mathrm{m}^{2}\right)$.

\section{Discussion}

Regarding the composition of the sample studied, it is important to note that the 209 freshmen evaluated represented $25.1 \%$ of the students entering that particular university in that period. From 832 freshmen, 527 (65.3\%) were women. The predominance of females in our sample $(72 \%)$ was due essentially to a higher number of women entering that university at that time.

A high prevalence of RF for AS in this sample was observed. This is in accordance with the national and international literature, in which the prevalence of RF in young individuals was also high.

Alterations in lipid profiles are important in deter- 


\begin{tabular}{|lccc|}
\hline \multicolumn{4}{|c|}{ Table I - Data regarding serum total cholesterol and its fractions (HDL-C, LDL-C) and triglycerides levels (mg/dL) of the sample studied according to gender } \\
\hline Variable & & Female & Male \\
Total cholesterol & Min - Max & $106-260$ & $109-250$ \\
& Mean (SD) & $178.25(32.55)$ & $168.93(37.20)$ \\
HDL-c & Min - Max & $23-80$ & $24-80$ \\
& Mean (SD) & $51.48(11.40)$ & $44.72(11.23)$ \\
LDL-c & Min - Max & $17-182$ & $51-174$ \\
& Mean (SD) & $99.25(29.86)$ & $98.76(31.06)$ \\
Triglicérides & Min - Max & $48-397$ & $57-399$ \\
& Mean (SD) & $112.85(46.38)$ & $129.03(68.75)$ \\
\hline
\end{tabular}

mining the development of AS ${ }^{16}$. The indices of mortality due to CHD are directly related to the mean serum TC levels of the population ${ }^{17}$. The mean TC level in this study was $172.05 \pm 33.86 \mathrm{mg} / \mathrm{dL}$, and there was no statistically significant difference between the mean values for men and women. In Brazil, Gerber and Zielinsky ${ }^{18}$, evaluating students who were 6 to 16 years of age, both from public and private school systems, reported a mean TC of 167.22 \pm 30.57. Forti et al ${ }^{19}$, despite having included in their study only young people with a positive family history, obtained similar data. A mean $<150 \mathrm{mg} / \mathrm{dL}$ was described by Bertolami et $\mathrm{al}^{20}$ in the group aged 14 to 21 years. The reduced number of individuals in this group ( $\mathrm{N}=80)$ may have been responsible for the finding. Regarding the national studies evaluating individuals in the age group of 20 to 29 years, the greatest mean of TC observed did not exceed $200 \mathrm{mg} / \mathrm{dL}^{21-24}$.

Although the means of TC, in most of the Brazilian studies, were not elevated, the frequency of undesirable levels was very high regardless of the age range and region of the country. In the study by Gerber and Zielinsky ${ }^{18}$, of 1502 students who were 6 to 16 years old, $27.8 \%$ of the sample had TC levels $>180 \mathrm{mg} / \mathrm{dL}$. Studies carried out in the states of Bahia ${ }^{25}$, Rio Grande do Sul ${ }^{21}$ and São Paulo ${ }^{23}$, in the adult population, showed similar proportions of undesirable TC levels (>35\% full sample). In our study, $9.1 \%$ of the freshmen had increased TC levels. This proportion increases to $36.8 \%$ if we consider those with TC levels above the desirable values. Regarding the international studies, $24 \%$ of the young people evaluated in the Muscatine Study had TC levels $>200 \mathrm{mg} / \mathrm{dL}^{26}$. In the Framingham Heart Study ${ }^{27}, 48 \%$ of the men and $26 \%$ of the women aged 31 to 39 years had TC levels $>220 \mathrm{mg} / \mathrm{dL}$.

In the present study, the mean LDL-C was lower than $100 \mathrm{mg} / \mathrm{dL}$ in both genders. Considering the whole sample, $26.3 \%$ had LDL-C levels above the desirable levels and $7.6 \%$ of the sample had increased levels. There was no significant association of LDL-C levels with gender. The frequency of subjects with undesirable LDL-C levels, an important risk predictor for AS, was also elevated in other Brazilian studies ${ }^{20,23}$.

A mean HDL-c of $>45 \mathrm{mg} / \mathrm{dL}$ was observed in individuals of both genders but it was higher in women. Most of the sample had desirable HDL-C levels ( $94.7 \%$ of the women and $82.8 \%$ of the men). However, while the percentage of men with low levels was $17.2 \%$, the percentage of women was only $5.3 \%$. Other national studies showed mean levels

\begin{tabular}{|c|c|c|c|c|}
\hline \multirow[t]{2}{*}{ Variable } & $\begin{array}{c}\text { Female } \\
(\mathrm{N}=151)\end{array}$ & $\begin{array}{c}\text { Male } \\
(\mathrm{N}=58)\end{array}$ & $\begin{array}{c}\text { Total } \\
(\mathrm{N}=209)\end{array}$ & $\mathrm{P}$ \\
\hline & $\mathrm{N}^{\circ}(\%)$ & $\mathrm{N}^{\circ}(\%)$ & № (\%) & \\
\hline \multicolumn{5}{|l|}{ Age range } \\
\hline 17 to 19 years of age & $84(76.4)$ & $26(23.6)$ & $110(100)$ & $0.212^{\mathrm{Y}}$ \\
\hline 20 to 25 anos years of age & $67(67.7)$ & $32(32.3)$ & $99(100)$ & \\
\hline Positive familial history & $34(82.9)$ & $7(17.1)$ & $41(100)$ & $0.131^{\mathrm{Y}}$ \\
\hline Hypertension & $13(39.4)$ & $20(60.6)$ & $33(100)$ & $<0.001^{\mathrm{Y}}$ \\
\hline Smoking & $24(72.7)$ & $9(27.3)$ & $33(100)$ & $0.884^{\mathrm{Y}}$ \\
\hline Sedentary life style & $119(72.1)$ & $46(27.9)$ & $165(100)$ & $0.912^{\mathrm{Y}}$ \\
\hline \multicolumn{5}{|l|}{ Body mass index } \\
\hline - Undernourished & $19(86.4)$ & $3(13.6)$ & $22(100)$ & $0.085^{\mathrm{Y}}$ \\
\hline - Eutrophic & $100(75.2)$ & $33(24.8)$ & $133(100)$ & $* *$ \\
\hline - Degree I overweight & $23(59.0)$ & $16(41.0)$ & $39(100)$ & \\
\hline - Degree II overweight & $8(57.1)$ & $6(42.9)$ & $14(100)$ & \\
\hline - Degree III overweight & $1(100)$ & $0(0.0)$ & $1(100)$ & \\
\hline High intake of total fat & $36(76.6)$ & $11(23.4)$ & 47 (100) & $0.568^{Y}$ \\
\hline High intake of cholesterol & $103(76.9)$ & $31(23.1)$ & $134(100)$ & $0.067^{\mathrm{Y}}$ \\
\hline
\end{tabular}


of HDL-C $>45 \mathrm{mg} / \mathrm{dL}$ in individuals $<20$ years old ${ }^{18,19}$ and $>40 \mathrm{mg} / \mathrm{dL}$ in individuals from this age on ${ }^{20,28,29}$. Regarding gender, Kannel et al ${ }^{30}$ report higher HDL-C levels in women regardless of age. In addition, HDL-C shows a strong inverse relation to sexual maturation in white men ${ }^{31}$.

Regarding TGs, their mean in this study was $<120 \mathrm{mg} /$ $\mathrm{dL}$ and $16.3 \%$ of the sample showed increased TG levels. Despite the small age difference, it is remarkable that 20 to 25-year-old individuals showed TG means significantly greater than those 17 to 19 years of age. As alcohol consumption may lead to hypertriglyceridemia by increasing hepatic TG synthesis ${ }^{32}$, one may speculate that there is an increase of alcohol ingestion among 20 to 25 -year-old students.

Sedentary life style in this study was the most prevalent risk factor among the students evaluated. It is known that, currently, television, video games and computers occupy a great part of young people's free time ${ }^{33}$. However, in regard to reduction in physical activity in the group studied, one may speculate about the involvement of other factors. Lack of interest in schools in promoting this kind of activity, mainly in the year preceding the entrance to the university; nonexistence of physical education classes in college preparatory courses, and reduction in extracurricular activities in this period may have contributed to the elevated frequency of sedentary life styles seen (78.9\%).

In the present study, there was an association between sedentary life style and increased LDL-C and TG levels. These findings support those in the literature. However, we found no association with diminished levels of HDL-C.

From the environmental variables involved in the determination of lipid profiles, diet is considered one of the most important ${ }^{34}$. Excessive caloric intake of fat and cholesterol is associated with increased serum levels of TC and LDL-C ${ }^{35}$. In our study, $77.5 \%$ of the sample showed total fat intake $>30 \%$ of the total calories and $35.9 \%$ showed cholesterol intake $\geq 300 \mathrm{mg} /$ day. Despite the high frequency of individuals with undesirable food habits, no association between lipoprotein alterations and high intake of total fat and cholesterol was observed. The fact that our nutritional evaluation did not identify the saturated fat portion of the diet may have contributed to the absence of this association. In addition, only a few intrapopulation epidemiological studies reported a consistent association of diet with levels of serum lipids ${ }^{36}$. This association is clearer in studies aiming to compare different populations, such as the Seven Countries Study ${ }^{37}$. In this study, the strong association of fat intake with serum cholesterol levels, seen in comparing different cohorts, was not observed in any particular cohort. As mentioned by Dressler et $\mathrm{al}^{28}$, intraindividual variability, both in the diet and in serum cholesterol levels, may reduce the possibility of detecting the presence of associations in one population. However, "random" variations may be minimized by obtaining the mean among individuals, which allows demonstration of possible associations in comparing different populations.
In our study, $19.6 \%$ of the sample had a positive family history and its association with lipid profile alteration was not observed. Several studies reveal the greater prevalence of RF in $1^{\text {st }}$ degree relatives of individuals with manifest AS, when compared with those without family history for this disease ${ }^{38}$. Forti et al ${ }^{19}$ observed elevated frequency of lipid metabolism changes and of body weight increase in children and adolescents of young patients with coronary heart disease. In comparing the prevalence of primary dyslipidemias among $1^{\text {st }}$ degree relatives of revascularized coronary heart disease patients and individuals without CHD familial history, Giannini et al ${ }^{29}$ reported greater frequency of improper lipid levels in the first group. Other authors did not find this relation. However, in the study by Gerber and Zielinsky ${ }^{18}, 61.67 \%$ of the students with hypercholesterolemia did not have positive familial history for AS. These data are similar to those reported in the Bogalusa Heart Study ${ }^{39}$, in which familial history was positive only in $40 \%$ of the young white hypercholesterolemic people and $21 \%$ of the black hypercholesterolemic people.

The relation between diastolic and systolic pressure levels and cardiovascular risk has already been very well established. In the present study, $15.8 \%$ of the students had hypertension, and $60.6 \%$ of them were men. Hypertension also predominated in 20 to 39 -year-old men in the study by Martins et al ${ }^{40}$. As already mentioned in the introduction, pressure levels tend to be higher in young males ${ }^{41}$. Some studies reported an association of hypertension with increased cholesterol levels ${ }^{24,40,42}$; this association, however, was not observed in our study.

The frequency of smokers observed in this sample was $15.8 \%$. From adolescence on, smoking is one of the most harmful influences in the progression of atherosclerotic plaque ${ }^{6}$. Craig et al ${ }^{43}$ showed through metaanalysis that smoking relates to reduction in the HDL-C levels in individuals aged 8 to 19 years, similarly to that which occurs in adults. However, like Forti et al ${ }^{19}$, we did not observe any association between the variables of the lipid profile and smoking. The different criteria used to determine the presence of smoking may contribute to the disagreement regarding this association. In the Framingham Heart Study ${ }^{44}$, $\mathrm{CHD}$ risk was related to the number of cigarettes smoked per day. A consumption $>10$ cigarettes per day related to lipoprotein alterations (higher TC and LDL-C levels in addition to lower HDL-C levels).

Obesity (BMI $\geq 30 \mathrm{~kg} / \mathrm{m}^{2}$ ) was observed in $7.2 \%$ of our sample, of which $60 \%$ were females and $40 \%$ males. Although analyzing a younger age range, Gerber and Zielinsky ${ }^{18}$ also reported a relatively low frequency $(6.33 \%)$ of obesity. Other studies, however, report a higher incidence of obesity ${ }^{19,45}$. Regarding BMI, the undernourishment among students in a private university in São Paulo should be noted $(10.5 \%)$. Possibly due to the current beauty trend emphasizing thinness and the stronger social pressure upon women, it was observed that the most undernourished individuals were females $(86.4 \%)$.

In our study, a statistically significant BMI asso- 
ciation with serum TC, LDL-C, and TG levels was observed. BMI showed a directly proportional relationship with serum TC and LDL-C levels. The greater the BMI, the greater the percentage of levels of these substances above the desired values. The greatest percentage of increased serum TG levels was observed in degrees II and III overweight students. These data agree with those in the literature ${ }^{40}$. Regarding HDL-C levels, despite the lack of a statistically significant association with BMI, the greatest percentage of low serum HDL-C levels was observed in degree II and III overweight individuals.

Diabetes mellitus is among the main causes of minor dyslipidemias. The Brazilian studies involving RF and AS analysis do not discuss diabetes mellitus, either by excluding diabetic individuals or by not making them present in their samples. In this study, none of the students had fasting glycemia levels $>126 \mathrm{mg} / \mathrm{dL}$.

In conclusion, it is appropriate to remember that studies aiming to characterize the risk profile of a population constitute the first step in elaborating preventive plans, allowing preventive measures to be adequate for the local reality in which they will be implemented, thus assuring their success. The present study draws attention to the elevated prevalence of RF for AS in adolescents and young adults. The involvement of the universities not only in the evaluation of the risk profile of their students but also in the educational process and the dissemination of the benefits of adopting a healthier life style would be very helpful in implementing a preventive plan for university students.

\section{References}

1. Watanabe T,HaraokaS, ShimokamaT. Inflammatory and immunological nature of atherosclerosis. Int J Cardiol 1996; 54(suppl): S25-S34.

2. Consigny PM. Pathogenesis of atherosclerosis. AJR 1995; 164: 553-8

3. Ministério da Saúde, DNDCD, SNPES. Controle das doenças não transmissíveis no Brasil. 1986: 19.

4. Lefant C, Savage PJ. The early natural history of atherosclerosis and hypertension in the young: National Intitutes of Health Perspectives. Am J Med Scienc 1995; 310(suppl 1): S3-S 7.

5. Holman RL, McGill HC, Strong JP, Geer JC. The natural history of atherosclerosis - the early aortic lesions as seen in New Orleans in the middle of the 20th century. Am J Pathol 1958; 34: 209-29.

6. Komatsu A, Sakuri I. Pathobiological Determinants of Atherosclerosis in Youth (PDAY) Research Group - A study of the development of atherosclerosis in childhood and young adults: Risk factors and the prevention of progression in Japan and the USA. Pathol Intern 1996; 46: 541-7.

7. Pathobiological Determinants of Atherosclerosis in Youth (PDAY) Research Group. Natural history of aortic and coronary athersclerotic lesions in youth : Findings from the PDAY study. Arterioscler Thromb 1993; 13: 1291-8.

8. Wissler RW, PDAY Collaborating Investigators. New insights into the patogenesis of atherosclerosis as revealed by PDAY. Atherosclerosis 1994; 108(suppl): 3-20.

9. Kannel WB, D'Agostino RB, Belanger AJ. Concep of bridging the gap from youth to adulthood. Am J Med Scienc 1995; 310(suppl 1): S15-S21.

10. Berenson GS. Prevention of heart disease beginning in childhood through comprehensive school health: the Heart SmartProgram. Prev Med 1993;22:507-12.

11. Grupo de Estudos e Pesquisa em Aterosclerose (GEPA). Segundo Consenso Brasileiro sobre Dislipidemias: detecção, avaliação e tratamento. Arq Bras Cardiol 1996; 63(supl): 1-13.

12. Joint National Committee. Report of the $V$ Joint National Committee on detection, evaluation, and treatment of high blodd pressure. Arch Intern Med 1993; 153: 154-83.

13. The Expert Committee on the Diagnosis and Classification of Diabetes Mellitus. Report of The Expert Committee on the Diagnosis and Classification of Diabetes Mellitus. Diabetes Care 1997; 20: 1183-97.

14. World Health Organization (WHO). Physical Status: the use and interpretation of anthropometry. Geneve, WHO, 1995. (Technical Report Series, 854).

15. La Vechia C, Franceschi S, Decarli A, Fasoli M, Gentile A, Tognoni G. Cigarette smoking and risk of cervical neoplasia. Am J Epidemiol 1986; 123: 365-74.

16. Baker AL, Roberts $\mathrm{C}$, Gothing C. Dyslipidemias in childhood. An overview. Nurs Clin North Am 1995; 30: 243-8.

17. Arnold CB. Heart disease mortality: international comparations. Stat Bull Metrop Insur Co 1993; 74: 19-26.

18. GerberZRS, Zielinsky P. Fatores de risco de aterosclerose na infância. Um estudo epidemiológico. Arq Bras Cardiol 1997; 69: 231-6.

19. Forti N, Giannini SD, Diament J, et al. Fatores de risco para doença arterial coronariana em crianças e adolescentes filhos de coronariopatas jovens. Arq Bras Cardiol 1996; 66: 119-23.

20. Bertolami MC, Faludi AA, Latorre MR, Zaidan Filho T. Perfil lipídico de funcionários de indústria metalúrgica e sua relação com outros fatores de risco. Arq Bras Cardiol 1993; 60:293-9.
21. Duncan BB, Berger C, Silva MLS, Bassanesi SL, Achutti AC. Níveis séricos de colesterol em amostra representativa da população adulta de Porto Alegre. Arq Bras Cardiol 1988; 51: 385-90.

22. Martins IS, Gomes AA, Pasini U. Níveis lipêmicos e alguns fatores de risco de doenças cardiovasculares em população do município de São Paulo, SP (Brasil). Rev Saúde Pública 1989; 23: 26-38.

23. Nicolau JC, Bechara DL, Nascimento SG, Greco OT, Jacob JLB, Lorga AM. Perfil do colesterol na cidade de São José do Rio Preto. Arq Bras Cardiol 1992; 59: 433-9.

24. Martins IS, Marucci MFN, Cervato AM, Okani ET, Mazzilli RN, Casajus MI. Doenças cardiovasculares ateroscleróticas, dislipidemias, hipertensão, obesidade e diabetes melito em população da área metropolitana da região sudeste do Brasil: II-dislipidemias. Rev Saúde Pública 1996; 30: 75-84.

25. Guimarães A, Lima JC. Perfil do nível de colesterol sangüíneo em comunidades bahianas. Arq Bras Cardiol 1991; 57(supl C): C15.

26. Lauer RM, Connor WE, Leaverton PE, Reiter MA, Clark WR. Coronary heart diseaserisk factors in school children: The Muscatine Study. J Pediatr 1975; 86: 697-706.

27. Anderson KM, Castelli WP, Levy DL. Cholesterol and mortality: 30 years of follow-up from Framingham Study. JAMA 1987; 257: 2176-80.

28. Dressler WW, Santos JE, Viteri FE, Gallagher Jr PN. Social and dietary predictors of serum lipids: a brazilian example. Soc Sci Med 1991; 32: 1229-35.

29. Giannini SD, Deveriacki BE, de Góis JM, et al. Prevalência de dislipidemias primárias em indivíduos com e sem história familiar de coronariopatia, tendo como referência os valores do National Cholesterol Education Program (NCEP). Arq Bras Cardiol 1992; 58: 281-7.

30. Kannel WB, Wilson PWF. An update on coronary risk factors. Med Clin North America 1995; 79: 951-71.

31. Freedman DS, Srinivasan SR, Webber LS, Burke GL, Berenson GS. Black-white differences in serum lipoproteins during sexual maturation: the Bogalusa Heart Study. J Chronic Dis 1987; 40: 309-18.

32. Durrington PN. Secondary hyperlipidaemia. Br Med Bull 1990; 46: 1005-24.

33. Harsha DW. The benefits of physical activity in chilhood. Am J Med Scienc 1995; 310(supl 1): S109-S13.

34. Nicklas TA. Dietary studies of children and young adults (1973-1988): the Bogalusa Heart Study. Am J Med Scienc 1995; 310(suppl 1): S101-8.

35. Grundy SM. Dietary Therapy of Hyperlipidemia. In: William J. Gabello Slide Atlas of Lipid Disorders, $3^{\text {rd }}$ ed. New York: Gower Medical Publishing, 1990: 35.

36. Shekelle RB, Shryock AM, Oblesby P. Diet, serum cholesterol, and death from coronary heart disease: the Western Eletric Study. NEngl J Med 1981; 304: 65-70.

37. Keys A, Menotti A, Karvonen MJ, et al. The diet and 15-year death rate in the Seven Coutries Study. Am J Epidemiol 1986; 124: 903-15.

38. Jorde-Williams RR. Relation between family history of coronary heart disease and coronary risk variables. Am J Cardiol 1988; 62: 708-13.

39. Dennison BA, Kikuchi DA, Srinivasan SR, Webber LS, Berenson GS. Parental history of cardiovascular disease as indication for screening for lipoprotein abnormalities in children. J Pediatr 1989; 115: 186-94.

40. Martins IS, Coelho LT, Matos IMS, Mazzilli RN, Trigo M, Wilson D. Dislipidemias e alguns fatore de risco associados em uma população periférica da região 
metropolitana de São Paulo, SP - Brasil. Um estudo piloto. Rev Saúde Pública 1989; 23: 236-43

41. Burt VL, Cutler JA, Higgins M. Trends in the prevalence, awareness, treatment, and control of hypertension in the adult U.S. population: data from the health examination surveys, 1960 to 1991 . Hypertension 1995; 26: 60-9.

42. Bonna KH, Thelle DS. Association between blood pressure and serum lipids in a population. The Tromso Study. Circulation 1991; 83: 1305-14.

43. Craig WY, Palomaki GE, Johnson AM, Haddow JE. Cigarette smoking- associated changes in blood lipid and lipoprotein levels in 8 to 19 years old group: a meta analysis. Pediatrics 1990; 85: 155-8

44. Kannel WB. CHD risk factors: A Framingham Study update. Hosp Pract 1990; 15: $119-30$.

45. Berenson GS, Wattigney WA, Tracy RE. Atherosclerosis of the aorta and coronary arteries and cardiovascular risk factors in persons aged 6 to 30 years and studied at necropsy: the Bogalusa Heart Study. Am J Cardiol 1992; 70 : 851-8. 